\title{
VARIANCE ANALYSIS IN MANUFACTURING COMPANIES
}

\author{
Marko Milojević1*, Lidija Barjaktarović ${ }^{1}$, Zlatomir Milošev ${ }^{2}$ \\ ${ }^{1}$ Singidunum University, Faculty of Business in Belgrade, 32 Danijelova Street, Belgrade, Serbia \\ ${ }^{2}$ FCA Serbia d.o.o., 4 Kosovska Street, Kragujevac, Serbia
}

\begin{abstract}
:
In dynamic and constantly changing contemporary business conditions, it is of key importance to dispose of adequate and relevant information on movements in the manufacturing process and to make adequate business decisions. Traditional accounting is not able to respond to all challenges, and thus it is necessary to enable better understanding of the manufaturing processes and the effects of various factors on the final outcomes and product costs. Several different models of cost accounting have been proposed with certain advantages and flaws, depending on the complexity of production and management requirements. Variance analysis is a tool that financial controllers and corporate financial managers use to interpret variations in operating results compared to the result envisaged by the budget or budget revision throughout the year.

The aim of this paper is to analyse the effects of variance analysis in the manufacturing company as a result of its good managerial accounting. The subject of this paper is one company, and its course from the budget as the basis for implementation of variance analysis, to realization and explanation of discrepancies between these two scenarios.
\end{abstract}

\author{
Key words: \\ variance analysis, \\ budget, \\ planning, \\ management, \\ business results.
}

\section{INTRODUCTION}

It is hard to imagine business of a contemporary, globally - oriented company without the follow-up and necessary information on the manufacturing process. Apart from being correct and true, information also needs to be provided in the right place and at the right time. In the contemporary business world, belated piece of information has no value and it is almost valueless. Variable analysis is one of the tools used by the managers to become conversant with the current business situation and provide favourable operating results in the future. More precisely, this paper places an emphasis on the variance analysis, which refers to examining the role, significance and possibility of using it in a manufacturing company.

The role of the analysis of variance is gaining more and more importance as managers want to know how corrections/ changes of specific input in manufacturing could affect operating results. Therefore, the analysis of variance could be defined as a tool used to detect deviations of the accomplished operating results compared to the expected results in the budget, which also represents the main goal of this research. Furthermore, it is used by a company's management to be able to clearly perceive all aspects of doing business, to react to potential problems in due time, and to eliminate these problems along with their associates with the aim of maximizing results and improving the company's productivity. The analysis of variance is done each month during 'the closing period' and it enables a company's management to analyse all anomalies in the company, to prepare action plans for the following periods in order to fix the anomalies (here we refer to negative anomalies, as positive anomalies imply the improvement of the results) and to avoid potential negative effects on the company's results. The analysis of variance proceeds from a company's budget, which is used to explain the current result through various variances (Hillier, 2006). As we have already mentioned, a month, a period or a whole year can be compared, having in mind that the analysis of variance at the end of the year cannot be used as a correction tool, but only as a final explanation for the deviation from the planned result. On the other hand, the analysis of variance for a month, and especially the analysis of variance for a period, represent a significant tool for the management by which they can take corrective measures in order to minimize the deviation from the planned result. The analysis of variance can be shown by table and graphs, depending on the level of details to be seen and the level of observation of the current results. 
The role of management accounting in a company is to help the management achieve optimal financial results, with reference to enhancing the company's productivity (Bierman, 1987; Gowthorpe, 2008; Petrovic, 2011). Therefore, the quality of management accountant has an immense impact on the prompt action of management in order to improve or mitigate the effects of input change in the production process (Marjanovic \& Milojevic, 2011). The division of costs into fixed and variable component and evaluation of their influence on cost price represent a challenge of each productionoriented and market-oriented company. All these actions are conducted with the aim of creating the budget which will be the business target (Barjatarovic et al., 2014). The effects of change of certain factors on the budget will be presented in the example of a manufacturing company. We will strive to describe all steps and phases during the observation and correction of the budget.

\section{RESULTS AND DISCUSSION}

Budget represent a company's plan for the following period. As such, it has to be created with maximum attention, taking into consideration all aspects that may affects operating result (Milojevic \& Miletic, 2014). All company's departments which support a company from the aspect of supply, sales, human resources etc, both manufacturing and organizational, should participate in the budget creation. Most often, the basis of the budget creation is sales plan and sales mix created by the sales sector. Based on the sales plan, other company sectors create the parts of budget related to their responsibilities.

As regard material costs, and based on the production component, the amount of the material necessary for production is calculated in accordance with the sales demands. An important aspect of material costs are material prices.

Table 1. Sales and sales mix

\begin{tabular}{|lrrrrrrrrrrrrr} 
Sales & Jan & \multicolumn{1}{c}{ Feb } & Mar & Apr & Maj & jun & \multicolumn{1}{c}{ Jul } & Avg & \multicolumn{1}{c}{ Sept } & Okt & \multicolumn{1}{c}{ Nov } & \multicolumn{1}{c}{ Dec } & \multicolumn{1}{c}{ Year } \\
Product A & 5,700 & 5,500 & 6,700 & 6,100 & 6,100 & 6,700 & 7,000 & 3,350 & 6,700 & 6,700 & 6,100 & 3,950 & 70,600 \\
Product B & 4,845 & 4,675 & 5,695 & 5,185 & 5,185 & 5,695 & 5,950 & 2,848 & 5,695 & 5,695 & 5,185 & 3,358 & 60,010 \\
Overall & $\mathbf{1 0 , 5 4 5}$ & $\mathbf{1 0 , 1 7 5}$ & $\mathbf{1 2 , 3 9 5}$ & $\mathbf{1 1 , 2 8 5}$ & $\mathbf{1 1 , 2 8 5}$ & $\mathbf{1 2 , 3 9 5}$ & $\mathbf{1 2 , 9 5 0}$ & $\mathbf{6 , 1 9 8}$ & $\mathbf{1 2 , 3 9 5}$ & $\mathbf{1 2 , 3 9 5}$ & $\mathbf{1 1 , 2 8 5}$ & $\mathbf{7 , 3 0 8}$ & $\mathbf{1 3 0 , 6 1 0}$
\end{tabular}

Table 2. Main material necessary for the production of two products

\begin{tabular}{rccccccccccccc}
\hline Main material in kg. & Jan & Feb & Mar & Apr & Maj & jun & Jul & Avg & Sept & Okt & Nov & Dec & Year \\
Product A & 17,100 & 16,500 & 20,100 & 18,300 & 18,300 & 20,100 & 21,000 & 10,050 & 20,100 & 20,100 & 18,300 & 11,850 & 211,800 \\
Product B & 12,113 & 11,688 & 14,238 & 12,963 & 12,963 & 14,238 & 14,875 & 7,119 & 14,238 & 14,238 & 12,963 & 8,394 & 150,025 \\
Overal & $\mathbf{2 9 , 2 1 3}$ & $\mathbf{2 8 , 1 8 8}$ & $\mathbf{3 4 , 3 3 8}$ & $\mathbf{3 1 , 2 6 3}$ & $\mathbf{3 1 , 2 6 3}$ & $\mathbf{3 4 , 3 3 8}$ & $\mathbf{3 5 , 8 7 5}$ & $\mathbf{1 7 , 1 6 9}$ & $\mathbf{3 4 , 3 3 8}$ & $\mathbf{3 4 , 3 3 8}$ & $\mathbf{3 1 , 2 6 3}$ & $\mathbf{2 0 , 2 4 4}$ & $\mathbf{3 6 1 , 8 2 5}$ \\
\hline Main material in RSD. & Jan & Feb & Mar & Apr & Maj & jun & Jul & Avg & Sept & Okt & Nov & Dec & Year \\
Product A & 10000 & 10000 & 10000 & 10000 & 10000 & 10000 & 10000 & 10000 & 10000 & 10000 & 10000 & 10000 & 10000 \\
Product BI & 12000 & 12000 & 12000 & 12000 & 12000 & 12000 & 12000 & 12000 & 12000 & 12000 & 12000 & 12000 & 12000
\end{tabular}

Table 3. Estimate of direct hours based on production by product unit

\begin{tabular}{|c|c|c|c|c|c|c|c|c|c|c|c|c|c|}
\hline $\begin{array}{r}\text { Product A } \\
\text { Amount }\end{array}$ & $\begin{array}{l}\text { Jan } \\
5,700\end{array}$ & $\begin{array}{l}\text { Feb } \\
5,500\end{array}$ & $\begin{array}{l}\text { Mar } \\
6,700\end{array}$ & $\begin{array}{l}\text { Apr } \\
6,100\end{array}$ & $\begin{array}{l}\text { Maj } \\
6,100\end{array}$ & $\begin{array}{l}\text { jun } \\
6,700\end{array}$ & $\begin{array}{l}\text { Jul } \\
7,000\end{array}$ & $\begin{array}{l}\text { Avg } \\
3,350\end{array}$ & $\begin{array}{l}\text { Sept } \\
6,700\end{array}$ & $\begin{array}{l}\text { Okt } \\
6,700\end{array}$ & $\begin{array}{l}\text { Nov } \\
6,100\end{array}$ & $\begin{array}{l}\text { Dec } \\
3,950\end{array}$ & $\begin{array}{c}\text { Year } \\
70,600\end{array}$ \\
\hline Production hour & 3 & 3 & 3 & 3 & 3 & 3 & 3 & 3 & 3 & 3 & 3 & $3^{r}$ & 3 \\
\hline Number of hours & 17,100 & 16,500 & 20,100 & 18,300 & 18,300 & 20,100 & 21,000 & 10,050 & 20,100 & 20,100 & 18,300 & 11,850 & 211,800 \\
\hline Product B & Jan & Feb & Mar & Apr & Maj & jun & Jul & Avg & Sept & Okt & Nov & Dec & Year \\
\hline Amount & 4,845 & 4,675 & 5,695 & 5,185 & 5,185 & 5,695 & 5,950 & 2,848 & 5,695 & 5,695 & 5,185 & 3,358 & 60,010 \\
\hline Production hour & 3.75 & 3.75 & 3.75 & 3.75 & 3.75 & 3.75 & 3.75 & 3.75 & 3.75 & 3.75 & 3.75 & $3.75^{\prime \prime}$ & 3.75 \\
\hline Number of hours & 18,169 & 17,531 & 21,356 & 19,444 & 19,444 & 21,356 & 22,313 & 10,678 & 21,356 & 21,356 & 19,444 & 12,591 & 225,038 \\
\hline Overall & Jan & Feb & Mar & Apr & Maj & jun & Jul & Avg & Sept & Okt & Nov & Dec & Year \\
\hline Amount & 10,545 & 10,175 & 12,395 & 11,285 & 11,285 & 12,395 & 12,950 & 6,198 & 12,395 & 12,395 & 11,285 & 7,308 & 130,610 \\
\hline Production hour & 35,269 & 34,031 & 41,456 & 37,744 & 37,744 & 41,456 & 43,313 & 20,728 & 41,456 & 41,456 & 37,744 & 24,441 & 436,838 \\
\hline Amount Production hour & 3.34 & 3.34 & 3.34 & 3.34 & 3.34 & 3.34 & 3.34 & 3.34 & 3.34 & 3.34 & 3.34 & 3.34 & 3.34 \\
\hline
\end{tabular}

Table 4 . The necessary number of planned employees in the budget

\begin{tabular}{|c|c|c|c|c|c|c|c|c|c|c|c|c|c|}
\hline & Ian & Feb & Mar & Apr & Maj & jun & Jul & Avg & Sept & Okt & Nov & Dec & Year \\
\hline Theoretical days & 22 & 20 & 22 & 22 & 21 & 22 & 23 & 21 & 22 & 22 & 21 & 23 & 261 \\
\hline Working days & 19 & 18 & 22 & 20 & 20 & 22 & 23 & 11 & 22 & 22 & 20 & 13 & 232 \\
\hline Number of direct workers & 252 & 252 & 251 & 252 & 252 & 251 & 251 & 251 & 251 & 251 & 252 & 251 & 251 \\
\hline Number of indirect workers & 76 & 76 & 75 & 75 & 75 & 75 & 75 & 75 & 75 & 75 & 75 & 75 & 75 \\
\hline Number of administrative workers & 25 & 25 & 25 & 25 & 25 & 25 & 25 & 25 & 25 & 25 & 25 & 25 & 25 \\
\hline
\end{tabular}


The department/ sector of procurement which gives its predictions about the prices of direct material is in charge of this issue. Usually, they start with the current prices, based on which an estimation is given regarding the efficiency of procurement using better negotiating aspects and trends in commodities in the world market. This is how we reach planned cost of direct material. The table below shows direct material consumption in $\mathrm{kg}$, as well as the prices of direct materials. In order to simplify the table, we have examined the overall material necessary for the production of two finished products.

The following step is the time of production which is necessary in order to count the number of hours, i.e. the number of direct workers needed for production in order to satisfy the planned level of sales. The table below shows the estimate of the number of direct hours based on the production time by product unit. In our example, production time for product A and product B is 3 hours and 3.75 hours, respectively.

Based on the number of hours, the department of work analysis conducts calculation of the number of direct workers, as well as the number of indirect workers. The number of administrative workers is mostly based on the current situation, but also on the needs regarding new employments or reorganization plan which implies redundancy notices due to a decrease in the company's activities. Moreover, the number of working days needed for a certain level of production is also taken into consideration.

In continuation of this process, $\mathrm{HR}$ department gives an estimation of wage policy, starting from the current income level and including potential corrections planned for the following year. Along with this process, the manufacturing level of a company gives their estimations of transformation costs, regarding the level of internal write-offs, consumption of indirect material and maintenance material, as well as costs of manufacturing services.

Technical service gives an estimation of the usage of electrical energy based on the production and estimated costs of fuels, as well as an estimate of the costs of fuels in the future in cooperation with the procurement sector.

The aforementioned data are forwarded to Finance/Controoling department which systemizes them and creates the budget. Controlling department also does an estimation of amortization costs, based on the activated main means and

Table 5. Defining cost price in manufacturing company

\begin{tabular}{|c|c|c|c|c|c|c|c|c|c|c|c|c|c|}
\hline RSD & Jan & Feb & Mar & Apr & Maj & jun & Jul & Avg & Sept & Okt & Nov & Dec & Year \\
\hline Production volume & 10,545 & 10,175 & 12,395 & 11,285 & 11,285 & 12,395 & 12,950 & 6,198 & 12,395 & 12,395 & 11,285 & 7,308 & 130,610 \\
\hline Direct ho & 35,269 & 34,031 & 41,456 & 37,744 & 37,744 & 41,456 & 43,313 & 20,728 & 41,456 & 41,456 & 37,744 & 24,441 & 436,838 \\
\hline \multicolumn{14}{|r|}{$706,000,000$} \\
\hline Overall & $115,140,000$ & $111,100,000$ & $135,340,000$ & $123,220,000$ & $123,220,000$ & $135,340,000$ & $141,400,000$ & $67,670,000$ & $135,340,000$ & $135,340,000$ & $123,220,000$ & $79,790,000$ & $1,426,120,000$ \\
\hline Direct work & $14,107,500$ & $13,612,500$ & $16,582,500$ & $15,097,500$ & $15,097,500$ & $16,582,500$ & $17,325,000$ & $8,291,250$ & $16,582,500$ & $16,582,500$ & $15,097,500$ & $9,776,250$ & $174,735,000$ \\
\hline Indirect work & $4,232,250$ & $4,083,750$ & $4,974,750$ & $4,529,250$ & $4,529,250$ & $4,974,750$ & $5,197,500$ & $2,487,375$ & $4,974,750$ & $4,974,750$ & $4,529,250$ & $2,932,875$ & $52,420,500$ \\
\hline Administration & $1,511,248$ & $1,512,500$ & $1,507,500$ & $1,509,750$ & $1,509,750$ & $1,507,500$ & $1,506,522$ & $1,507,500$ & $1,507,500$ & $1,507,500$ & $1,509,750$ & $1,504,038$ & $18,101,058$ \\
\hline Internal write-offs & 57,0 & $5,555,000$ & $6,767,000$ & $6,161,000$ & b & 0 & $7,070,000$ & $3,383,500$ & $6,767,000$ & $6,767,000$ & $6,161,000$ & 00 & 000 \\
\hline Indirect material & 0 & & & & & & & & & & & & 8,400 \\
\hline Services & $18,000,000$ & $18,000,000$ & $18,000,000$ & $18,000,000$ & $18,000,000$ & $18,000,000$ & $18,000,000$ & $18,000,000$ & $18,000,000$ & $18,000,000$ & $18,000,000$ & $18,000,000$ & $216,000,000$ \\
\hline Energy & $40,299,000$ & $38,885,000$ & $47,369,000$ & $30,805,000$ & $30,805,000$ & $33,835,000$ & $35,350,000$ & $16,917,500$ & $33,835,000$ & $47,369,000$ & $43,127,000$ & $27,926,500$ & $426,523,000$ \\
\hline Other costs & $25,000,000$ & $25,000,000$ & $25,000,000$ & $25,000,000$ & $25,000,000$ & $25,000,000$ & $25,000,000$ & $25,000,000$ & $25,000,000$ & $25,000,000$ & $25,000,000$ & $25,000,000$ & $300,000,000$ \\
\hline & $1,859,298$ & $, 813,250$ & 092,050 & $94,630,400$ & $94,630,400$ & $99,558,050$ & $102,022,022$ & $72,032,775$ & $99,558,050$ & $113,092,050$ & $106,952,400$ & 213 & $1,184,178,958$ \\
\hline nsforma & $116,966,798$ & $114,425,750$ & $129,674,550$ & $109,727,900$ & $109,727,900$ & $116,140,550$ & $119,347,022$ & $80,324,025$ & $116,140,550$ & $129,674,550$ & $122,049,900$ & $94,714,463$ & $1,358,913,958$ \\
\hline & $11,884,333$ & $11,884,333$ & $11,884,333$ & $11,884,333$ & $11,884,333$ & $11,884,333$ & $11,884,333$ & $11,884,333$ & $11,884,333$ & $11,884,333$ & $11,884,333$ & $11,884,333$ & $142,612,000$ \\
\hline & $128,851,131$ & $126,310,083$ & $141,558,883$ & $121,612,233$ & $121,612,233$ & $128,024,883$ & $131,231,355$ & $92,208,358$ & $128,024,883$ & $141,558,883$ & $133,934,233$ & $106,598,797$ & $1,501,525,958$ \\
\hline Production costs & $243,991,131$ & $237,410,083$ & $276,898,883$ & $244,832,233$ & $244,832,233$ & $263,364,883$ & $272,631,355$ & $159,878,358$ & $263,364,883$ & $276,898,883$ & $257,154,233$ & $186,388,797$ & $2,927,645,958$ \\
\hline
\end{tabular}

Table 6. An example of introducing the division of costs into fixed and variable component

\begin{tabular}{|c|c|c|c|c|c|c|c|}
\hline RSD & Year & Var & Fiks & Var RSD & Fix RSD & Var RSD/h & Fix RSD/h \\
\hline \multirow{2}{*}{$\begin{array}{r}\text { Production volume } \\
\text { Direct hours }\end{array}$} & 130,610 & & & & & & \\
\hline & 436,838 & & & & & & \\
\hline \multicolumn{8}{|l|}{ Main material } \\
\hline Product A & $706,000,000$ & & & & & & \\
\hline Product B & $720,120,000$ & & & & & & \\
\hline Overall & $1,426,120,000$ & $100 \%$ & & $1,426,120,000$ & - & & \\
\hline Direct work & $174,735,000$ & $100 \%$ & & $174,735,000$ & - & 400 & - \\
\hline Indirect work & $52,420,500$ & $70 \%$ & $30 \%$ & $36,694,350$ & $15,726,150$ & 84 & 36 \\
\hline Administration & $18,101,058$ & & $100 \%$ & - & $18,101,058$ & - & 41 \\
\hline Internal write-offs & $71,306,000$ & $100 \%$ & & $71,306,000$ & - & 163 & - \\
\hline Indirect material & $99,828,400$ & $85 \%$ & $15 \%$ & $84,854,140$ & $14,974,260$ & 194 & 34 \\
\hline Services & $216,000,000$ & & $100 \%$ & - & $216,000,000$ & - & 494 \\
\hline Energy & $426,523,000$ & $50 \%$ & $50 \%$ & $213,261,500$ & $213,261,500$ & 488 & 488 \\
\hline Other costs & $300,000,000$ & & $100 \%$ & - & $300,000,000$ & - & 687 \\
\hline Load costs & $1,184,178,958$ & & & $406,115,990$ & $778,062,968$ & 930 & 1,781 \\
\hline Transformation costs & $1,358,913,958$ & & & $580,850,990$ & $778,062,968$ & 1,330 & 1,781 \\
\hline Amortization & $142,612,000$ & & $100 \%$ & - & $142,612,000$ & - & 326 \\
\hline Overall transformation costs & $1,501,525,958$ & & & $580,850,990$ & $920,674,968$ & 1,330 & 2,108 \\
\hline Production costs & $2,927,645,958$ & & & $2,006,970,990$ & $920,674,968$ & & \\
\hline
\end{tabular}


the level of amortization for each specific means, as well as based on the estimation of future investment in the production process and amortization for the activated main means in the future. This is how we reach all relevant costs necessary for calculation of cost price of our products.
In order to properly calculate cost price, we introduce the division of costs into variable, relatively fixed and fixed costs.

Based on the rate of fixity and variability, we are able to calculate the overall variable costs and overall fixed costs for the budget level of production and to define them according

Table 7. Defining cost price and selling price

\begin{tabular}{|c|c|c|}
\hline & Product A & Product B \\
\hline Material & 10,000 & 12,000 \\
\hline Variable costs/ h & 1,330 & 1,330 \\
\hline Fixed costs/h & 2,108 & 2,108 \\
\hline Transformation costs/h & 3,437 & 3,437 \\
\hline Production hours & 3 & 4 \\
\hline Transformation costs & 10,312 & 12,890 \\
\hline Cost price & 27,189 & 31,768 \\
\hline
\end{tabular}

\begin{tabular}{|r|r|r|}
\hline & Product A & Product B \\
\hline Material & $\mathbf{1 0 , 0 0 0}$ & $\mathbf{1 2 , 0 0 0}$ \\
\hline Variable costs/ $h$ & 1,330 & 1,330 \\
\hline Fixed costs/h & 2,108 & 2,108 \\
\hline Transformation costs/h & 3,437 & 3,437 \\
\hline Production hours & 3 & 4 \\
\hline Transformation costs & 10,312 & 12,890 \\
\hline Cost price & $\mathbf{2 7 , 1 8 9}$ & $\mathbf{3 1 , 7 6 8}$ \\
\hline Profit margin 10\% & 2,719 & 3,177 \\
\hline Selling price & $\mathbf{2 9 , 9 0 8}$ & $\mathbf{3 4 , 9 4 5}$ \\
\hline
\end{tabular}

Table 8. The budget of a manufacturing company

\begin{tabular}{|c|c|c|c|c|c|c|c|c|c|c|c|c|c|}
\hline RSD & Jan & Feb & Mar & Apr & Maj & jun & Jul & Avg & Sept & Okt & Nov & Dec & Year \\
\hline Production volume & 10,545 & 10,175 & 12,395 & 11,285 & 11,285 & 12,395 & 12,950 & 6,198 & 12,395 & 12,395 & 11,285 & 7,308 & 130,610 \\
\hline Direct hours & 35,269 & 34,031 & 41,456 & 37,744 & 37,744 & 41,456 & 43,313 & 20,728 & 41,456 & 41,456 & 37,744 & 24,441 & 436,838 \\
\hline Main material & $57,000,000$ & $55,000,000$ & $67,000,000$ & $61,000,000$ & $61,000,000$ & $67,000,000$ & $70,000,000$ & $33,500,000$ & $67,000,000$ & $67,000,000$ & $61,000,000$ & $39,500,000$ & $706,000,000$ \\
\hline $\begin{array}{l}\text { Product A } \\
\text { Product B }\end{array}$ & $58,140,000$ & $56,100,000$ & $68,340,000$ & $62,220,000$ & $62,220,000$ & $68,340,000$ & $71,400,000$ & $34,170,000$ & $68,340,000$ & $68,340,000$ & $62,220,000$ & $40,290,000$ & $720,120,000$ \\
\hline Overall & $115,140,000$ & $111,100,000$ & $135,340,000$ & $123,220,000$ & $123,220,000$ & $135,340,000$ & $141,400,000$ & $67,670,000$ & $135,340,000$ & $135,340,000$ & $123,220,000$ & $79,790,000$ & $1,426,120,000$ \\
\hline Direct work & $14,107,500$ & $13,612,500$ & $16,582,500$ & $15,097,500$ & $15,097,500$ & $16,582,500$ & $17,325,000$ & $8,291,250$ & $16,582,500$ & $16,582,500$ & $15,097,500$ & $9,776,250$ & $174,735,000$ \\
\hline Indirect work & $4,232,250$ & $4,083,750$ & $4,974,750$ & $4,529,250$ & $4,529,250$ & $4,974,750$ & $5,197,500$ & $2,487,375$ & $4,974,750$ & $4,974,750$ & $4,529,250$ & $2,932,875$ & $52,420,500$ \\
\hline Administration & $1,511,248$ & $1,512,500$ & $1,507,500$ & $1,509,750$ & $1,509,750$ & $1,507,500$ & $1,506,522$ & $1,507,500$ & $1,507,500$ & $1,507,500$ & $1,509,750$ & $1,504,038$ & $18,101,058$ \\
\hline e-offs & $5,757,000$ & $5,555,000$ & $6,767,000$ & $6,161,000$ & $6,161,000$ & $6,767,000$ & $7,070,000$ & $3,383,500$ & $6,767,000$ & $6,767,000$ & $6,161,000$ & $3,989,500$ & $71,306,000$ \\
\hline Indirect $\mathrm{m}$ & $8,059,800$ & $7,777,000$ & $9,473,800$ & 8,6 & 8,6 & 300 & 000 & ;,900 & 9,4 & 800 & 8,6 & 300 & $99,828,400$ \\
\hline Services & $18,000,000$ & $18,000,000$ & $18,000,000$ & $18,000,000$ & $18,000,000$ & $18,000,000$ & $18,000,000$ & $18,000,000$ & $18,000,000$ & $18,000,000$ & $18,000,000$ & $18,000,000$ & $216,000,000$ \\
\hline Energy & $40,299,000$ & $38,885,000$ & $47,369,000$ & $30,805,000$ & $30,805,000$ & $33,835,000$ & $35,350,000$ & $16,917,500$ & $33,835,000$ & $47,369,000$ & $43,127,000$ & $27,926,500$ & $426,523,000$ \\
\hline Other costs & $25,000,000$ & $25,000,000$ & $25,000,000$ & $25,000,000$ & $25,000,000$ & $25,000,000$ & $25,000,000$ & $25,000,000$ & $25,000,000$ & $25,000,000$ & $25,000,000$ & $25,000,000$ & $300,000,000$ \\
\hline 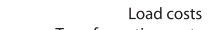 & 859,298 & $, 813,250$ & ,092,050 & 630,400 & $94,630,400$ & $99,558,050$ & $102,022,022$ & $72,0=$ & 99,5 & $113,092,050$ & 106,9 & $84,938,213$ & 8,958 \\
\hline Transformation costs & $116,966,798$ & $114,425,750$ & $129,674,550$ & $109,727,900$ & $109,727,900$ & $116,140,550$ & $119,347,022$ & $80,324,025$ & $116,140,550$ & $129,674,550$ & $122,049,900$ & $94,714,463$ & $1,358,913,958$ \\
\hline & $11,884,333$ & $11,884,333$ & $11,884,333$ & $11,884,333$ & $11,884,333$ & $11,884,333$ & $11,884,333$ & $11,884,333$ & $11,884,333$ & $11,884,333$ & $11,884,333$ & $11,884,333$ & $142,612,000$ \\
\hline erall transformation costs & $128,851,131$ & $126,310,083$ & $141,558,883$ & $121,612,233$ & $121,612,233$ & $128,024,883$ & $131,231,355$ & $92,208,358$ & $128,024,883$ & $141,558,883$ & $133,934,233$ & $106,598,797$ & $1,501,525,958$ \\
\hline Production costs & $243,991,131$ & $237,410,083$ & $276,898,883$ & $244,832,233$ & $244,832,233$ & $263,364,883$ & $272,631,355$ & $159,878,358$ & $263,364,883$ & $276,898,883$ & $257,154,233$ & $186,388,797$ & $2,927,645$ \\
\hline $\begin{array}{c}\text { Sales } \\
\text { Overall }\end{array}$ & $260,004,818$ & $250,881,842$ & $305,619,698$ & $278,250,770$ & $278,250,770$ & $305,619,698$ & $319,304,163$ & $152,809,849$ & $305,619,698$ & $305,619,698$ & $278,250,770$ & $180,178,777$ & $3,220,410,554$ \\
\hline Result & $16,013,687$ & 471,759 & $28,720,815$ & $33,418,537$ & $33,418,537$ & $42,254,815$ & $46,672,808$ & $7,068,509)$ & $42,254,815$ & $28,720,815$ & $21,096,537$ & $(6,210,019)$ & $292,764,596$ \\
\hline
\end{tabular}

Table 9. The example of corrected budget for current production volume

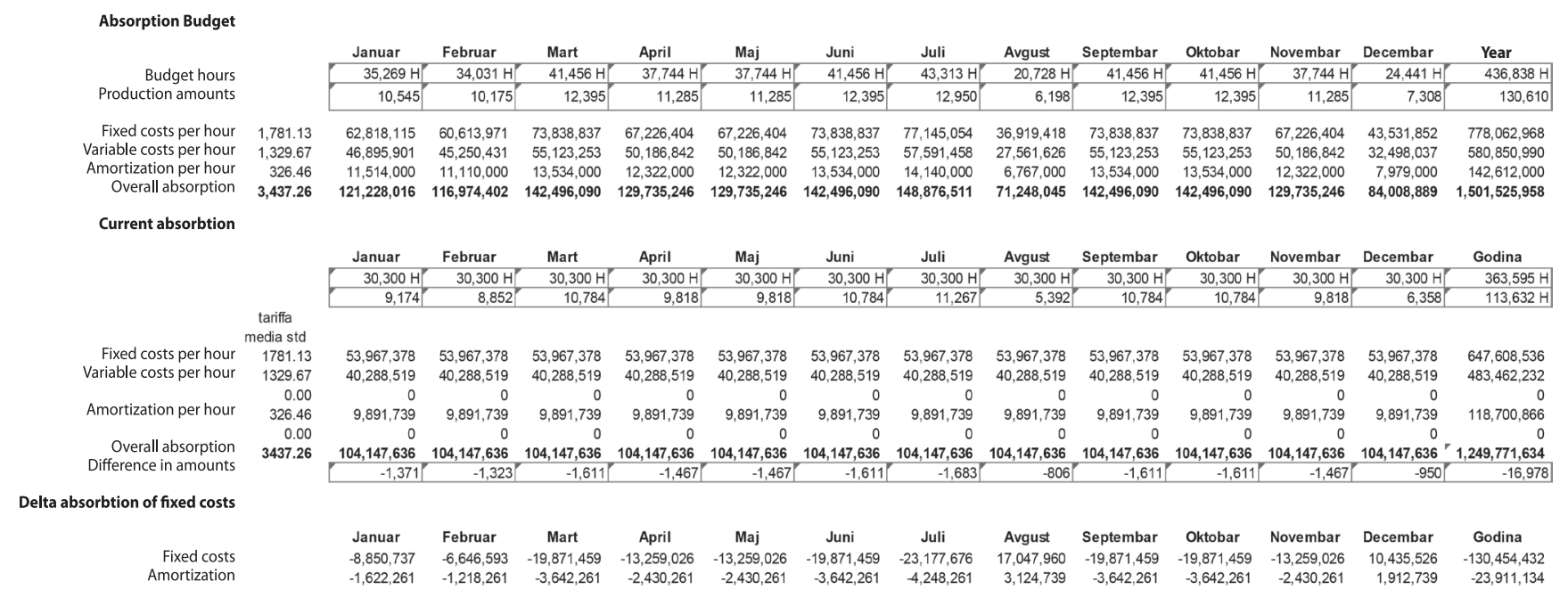


to the hour of production, as shown in Table 6. The Table shows that Variable costs per hour are 1,330 RSD, while Fixed costs per hour are 2,108 RSD. Based on these parameters, we can calculate the amount of transformation costs per unit of finished product. Eventually, by summation of costs of materials per unit and transformation costs per unit, we get the cost price of our finished products in the budget. For the purpose of this paper, we have defined selling price as the price which contains $10 \%$ of profit margin related to cost price in order to present selling prices as shown in the table below.

By calculating the selling price, we are able to create complete Income statement. Thus, our budget is ready to be approved by the company's management.

The above given example shows the company's budget of 292.7 million RSD. Eventually, we would like to highlight that the budget can be shown as the analysis of variance compared to the current situation. The parameters of the first eight months of the current year are mostly taken as the basis, along with forecasts for the following four months. The analysis of variance with $8+4$ assessment ( 8 current months and 4 evaluation months) is then done according to such scenario until the next year's budget, but this is not the subject of this paper.

\subsection{The Influence of Fixed Costs on the Results within Changes in the Production Volume - Absorption}

The characteristic of fixed costs is the fact that they remain the same in the absolute amount throughout the whole period, regardless of the production level. The best example for this is amortization, which is calculated once per year based on the percentage of amortization of each means, and depending on whether the means is the property, equipment or, for instance, a car. Based on this information, we can define various amortization rates. Based on the allocation of fixed and variable costs in the budget, we can define the absorption rate due to the change in the production level, i.e. due to the influence of fixed costs per hour of direct work. This is very significant as we can depict the actual production level with budget parameters, the so-called Flex Budget or Corrected Budget, i.e. budget corrected for the current production level.

The above-given table shows the difference in the absorption of fixed costs due to the decrease in the scope of production. In our example, this difference is 154 million RSD.

Table 10. The influence of the change in manufacturing mix on the revenues of a manufacturing company

$\begin{array}{rrrr} & \text { Product A } & \text { Product B } & \text { Overall } \\ \text { Material } & 10,000 & 12,000 & \\ \text { Variable costs/h } & 1,330 & 1,330 & \\ \text { Fixed costs/h } & 2,108 & 2,108 & \\ \text { Transformation costs/h } & 3,437 & 3,437 & \\ \text { Production hours } & 3 & 4 & \\ \text { Transformation costs } & 10,312 & 12,890 & \\ \text { Cost price } & \mathbf{2 0 , 3 1 2} & \mathbf{2 4 , 8 9 0} & \\ \text { Profit margin } & 2,031 & 2,489 & \\ \text { Selling price } & \mathbf{2 2 , 3 4 3} & \mathbf{2 7 , 3 7 9} & \\ & & & \\ \text { Budget-sales kom } & 70600 & 60010 & 130610 \\ \text { Revenues 000/RSD } & 1,577,414 & 1,642,997 & 3,220,411 \\ & & & \\ \text { Realization-sales; } & 60010 & 70600 & 130610 \\ \text { Revenues 000/RSD } & 1,340,802 & 1,932,937 & 3,273,739 \\ \text { Difference 000/RSD } & (236,612) & 289,941 & 53,329\end{array}$

Table 11. An example of Flex Budget of a manufacturing company

\begin{tabular}{|c|c|c|c|}
\hline The analysis of variance $000 /$ RSD & Budget & Vol Mix & Budget flex \\
\hline Production volume & 130,610 & $-16,978$ & 113,632 \\
\hline Direct hours & 436,838 & $-61,548$ & 375,289 \\
\hline Working days & 232 & 0 & 232 \\
\hline Direct material costs & $1,426,120$ & $-169,760$ & $1,256,360$ \\
\hline Direct labour costs & 174,735 & $-21,230$ & 153,505 \\
\hline Indirect labour & 52,421 & 141 & 52,562 \\
\hline Administration & 18,101 & $-7,220$ & 10,881 \\
\hline Labour costs & 245,257 & $-28,309$ & 216,947 \\
\hline Material write-offs & 71,306 & $-10,047$ & 61,259 \\
\hline Indirect material & 99,828 & $-11,955$ & 87,873 \\
\hline Services & 216,000 & 0 & 216,000 \\
\hline Energy costs & 426,523 & $-50,606$ & 375,917 \\
\hline Other costs & 300,000 & 0 & 300,000 \\
\hline Load costs & $1,184,179$ & $-79,687$ & $1,104,492$ \\
\hline Transformation costs & $1,358,914$ & $-100,917$ & $1,257,997$ \\
\hline Amortization & 142,612 & 0 & 142,612 \\
\hline Overall transformation costs & $1,501,526$ & $-100,917$ & $1,400,609$ \\
\hline Overall production costs & $2,927,646$ & $-270,677$ & $2,656,969$ \\
\hline Increase/ decrease in supply value & 0 & 0 & 0 \\
\hline COGS & $2,927,646$ & $-270,677$ & $2,656,969$ \\
\hline Overall sales & $3,220,411$ & $-393,721$ & $2,826,690$ \\
\hline Result & 292,765 & 123,043 & 169,721 \\
\hline
\end{tabular}




\subsection{The Influence of the Change of Manufacturing/Selling Programme - Mix}

The influence of manufacturing/ selling mix is a change in the structure of production/ sales, i.e. different ratio between products. This influence is mostly small and it can lead to the increase or decrease in costs per production unit, as, for example, products have different production time, different prices of direct material and different mix affects the overall result, if these differences in prices of specific products are significant. What does this imply? When a product mix is changed, there is a different allocation of costs as well as revenues, which might cause different results. In the example below, we present a difference in revenues due to different selling mix regarding the company's revenues. In this case, the overall sale has remained the same, but by changing manufacturing mix, higher revenues are accomplished. This does not automatically imply better result, but it definitely means a deviation in the budget which needs to be explained.

Eventually, by taking into consideration manufacturing/ selling mix and absorption, we get a budget corrected for the current level of production/ sales. The table below shows the budget created due to the decrease in production of 16 , 978 units, the corrected budget (Flex Budget) of 169.7 million RSD.

\subsection{The influence of effectiveness on the result}

Effectiveness is one the variances after defining the budget corrected for the current production level. The measurement of effectiveness is done for all production costs starting from the material. When we talk about effectiveness in material, we mostly refer to technical and technological solutions regarding the decrease in direct material per product unit, taking care of product quality and functionality (Cvetinovic, 2013). By using these technical and technological solutions, we are able to decrease cost price of material per product unit and to show effectiveness compared to the state in the time of budget creation. This is a continuous process and it depends on the technological progress of the industry branch to which the company belongs, competition and needs of target customers. Needless to say, this can sometimes lead to the increase in material costs due to quality needs or market demands, which is defined as ineffectiveness compared to the state during budget creation.

Direct labour is presented immediately after the material. Effectiveness in direct labour is shown in the time frame necessary to produce a finished product. Operational lists which contain a detailed description of each operation are used to measure production time. By analysing operational lists, work place, and by introducing new technological solutions in the production process, as well as minor improvements in automatization, we can decrease production time per product unit and therefore show effectiveness in direct labour. There is a whole study based on direct labour. It can be divided into value added activities and non-value added activities. By decreasing non-value added activities, we have an impact on our labour effectiveness. Another important aspect of direct labour is Saturation of workers. It stands for actual employment, i.e. workers' activities. The opposite term would be Desaturation, which practically represents the time a worker spends between two operations, due to technological process. By decreasing Desaturation we also affect labour effectiveness. Other costs follow labour analysis, such as costs of internal write-offs and indirect material. These costs are usually 100\% variable, which means that they depend directly on the production level. Furthermore, this implies that they can be followed along with production level as some type of key performance indicator and they can be defined as cost per product unit (PriceWartehouseCoopers, 2007). This is how we can conclude whether we are efficient in the realization or not, when compared to the budget. Relatively variable costs partly follow production volume and they are partly fixed. This means that one part of these costs stays fixed for all production stages. By focusing on the decrease in these costs, we affect both effectiveness and a certain amount of fixed costs per product unit, which can lead to positive overall effects.

Table 12. An example of variance of effectiveness of a manufacturing company

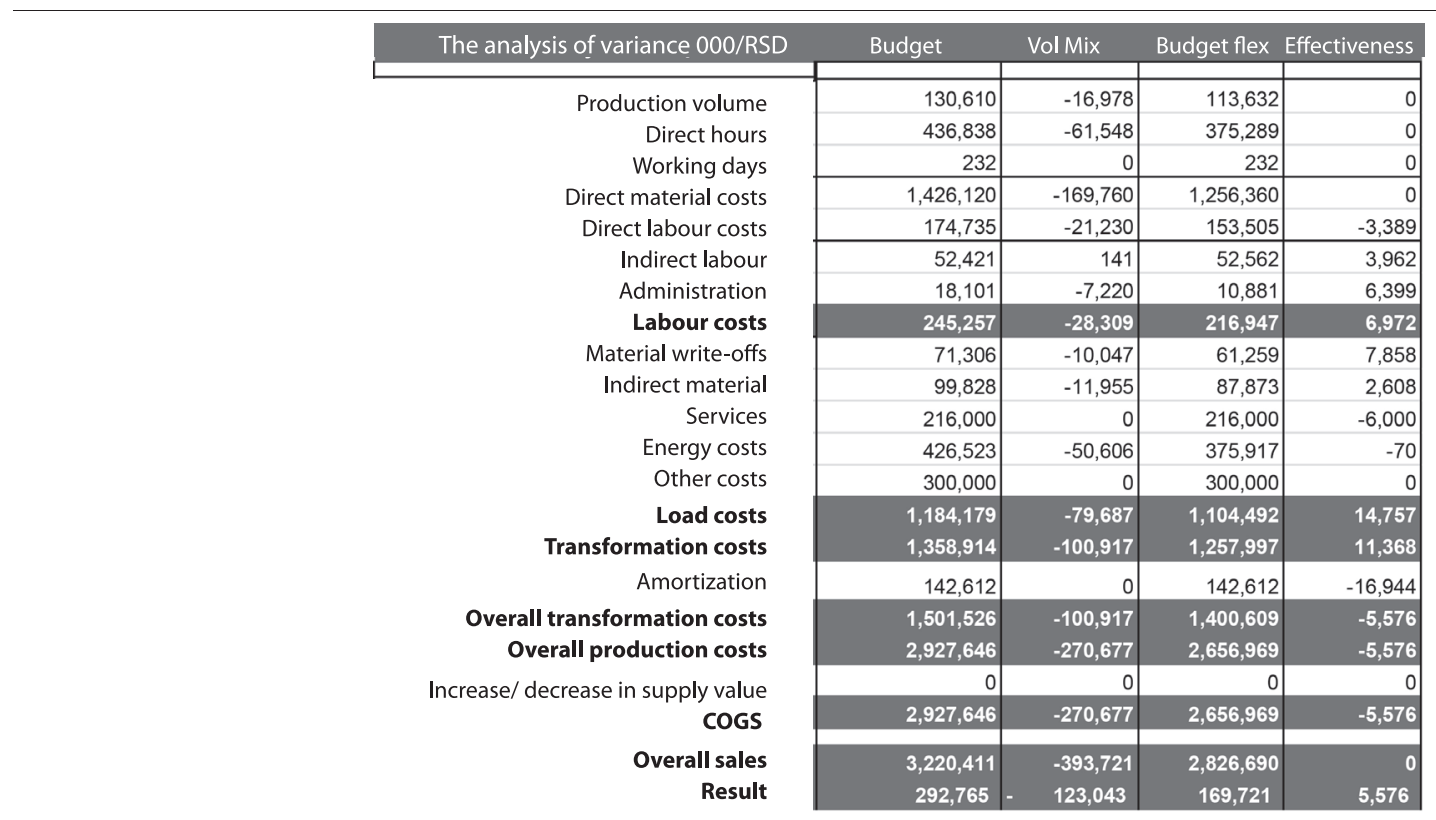


Energy costs can be very significant in some industrial branches, which implies bigger control of energy consumption by measuring the amount of used fuels, which is then compared to the planned amounts. Some companies install measurers in order to be able to follow energy consumption on a daily basis and to affect the level of energy consumption within the planned boundaries. As we have already mentioned, fixed costs do not depend on the production stage. Apart from the previously discussed amortization example, there is, for instance, the cost of production services which are mostly signed for the annual period. From the point of view of effectiveness, every takeover of these activities by a company will affect the effectiveness regarding these costs. Finally, we should say that effectiveness is under direct responsibility of people from the production department, i.e. production managers. Measurement of production performance, i.e. of production manager is done by this variance. The table below offers an example of effectiveness variance.

\subsection{The Influence of price change on result - Price variance}

Like effectiveness, price can be regarded in all production costs. In this paper, we have assumed that the selling prices have remained stable throughout the whole year, which does not have to be the case in practice. On the contrary, the analysis of variance and budget revision during the year can show the necessity for correction of selling prices if a company wants to do business successfully and maximize its profits.

First of all, we will consider price change of direct material. As direct material participates in the cost price in many industries, the deviation from the planned price can lead to huge fluctuations and deviations in the overall material. Therefore, the prices of direct material have to be followed carefully. The responsibility for the prices of direct material is in the hands of procurement sector and, of course, sector supervisor. Every deviation should be explained and the solution to the newly created problems has to be found.
What follows the material is labour cost. The policy of incomes is under direct responsibility of the HR department. However, time management is under the responsibility of sector supervisors. What does this mean? Every income increase affects the increase in timetable of direct and indirect workers, as well as payments of workers in administration. Overtime work which is not planned, as well as working on weekends and holidays, can also lead to increased labour costs which can be explained by price deviation. All those in charge have to take care of the fact that labour costs amount to planned limits in order to avoid any deviations. Otherwise, each of them has to explain what has happened. Energy costs are the next big expense. As it has already been mentioned, these costs are pretty high in some industries, so good estimation of future prices of fuels is of key significance. Any deviation from the planned cost is achieved when current spent amounts are multiplied with budget prices, and those values are subtracted from current costs.

\subsection{Analysis of Variance - Results - Overview}

The analysis of variance of results comes from two sides. On one hand, there is the planned result, which is corrected after the realization for the new product/ sales result. On the other hand, there are actual product costs and actual incomes due to sales of finished products. The difference between these values for every costs and income is explained by effectiveness and price variance. The variance of currency can also be included in the analysis, if a company is somehow connected to foreign countries in the area of ownership, material procurement and sales of finished products abroad. However, for the purpose of this paper, we have remained in the area of domestic economy. An overview of analysis of variance is shown in the table below.

Apart from the table overview, a graphic overview offers a better macro image which clearly shows deviations regarding responsibilities.

Table 13. Review of complete business result of a manufacturing company

\begin{tabular}{|c|c|c|c|c|c|c|}
\hline The analysis of variance $000 /$ RSD & Budget & Vol Mix & Budget flex & Effectiveness & Price & Realization \\
\hline Production volume & 130,610 & $-16,978$ & 113,632 & 0 & 0.00 & 113,632 \\
\hline Direct hours & 436,838 & $-61,548$ & 375,289 & 0 & 0.00 & 375,289 \\
\hline Working days & 232 & 0 & 232 & 0 & 0.00 & 232 \\
\hline Direct material costs & $1,426,120$ & $-169,760$ & $1,256,360$ & 0 & 320.22 & $1,256,680$ \\
\hline Direct labour costs & 174,735 & $-21,230$ & 153,505 & $-3,389$ & $15,011.58$ & 165,127 \\
\hline Indirect labour & 52,421 & 141 & 52,562 & 3,962 & 49.72 & 56,574 \\
\hline Administration & 18,101 & $-7,220$ & 10,881 & 6,399 & 864.00 & 18,144 \\
\hline Labour costs & 245,257 & $-28,309$ & 216,947 & 6,972 & $15,925.30$ & 239,845 \\
\hline Material write-offs & 71,306 & $-10,047$ & 61,259 & 7,858 & 0.00 & 69,117 \\
\hline Indirect material & 99,828 & $-11,955$ & 87,873 & 2,608 & 0.00 & 90,481 \\
\hline Services & 216,000 & 0 & 216,000 & $-6,000$ & 0.00 & 210,000 \\
\hline Energy costs & 426,523 & $-50,606$ & 375,917 & -70 & 0.00 & 375,847 \\
\hline Other costs & 300,000 & 0 & 300,000 & 0 & 0.00 & 300,000 \\
\hline Load costs & $1,184,179$ & $-79,687$ & $1,104,492$ & 14,757 & 914 & $1,120,163$ \\
\hline Transformation costs & $1,358,914$ & $-100,917$ & $1,257,997$ & 11,368 & 15,925 & $1,285,291$ \\
\hline Amortization & 142,612 & 0 & 142,612 & $-16,944$ & 0.00 & 125,668 \\
\hline Overall transformation costs & $1,501,526$ & $-100,917$ & $1,400,609$ & $-5,576$ & 15,925 & $1,410,959$ \\
\hline Overall production costs & $2,927,646$ & $-270,677$ & $2,656,969$ & $-5,576$ & 16,246 & $2,667,639$ \\
\hline Increase/ decrease in supply value & 0 & 0 & 0 & 0 & 0.00 & 0 \\
\hline cogs & $2,927,646$ & $-270,677$ & $2,656,969$ & $-5,576$ & 16,246 & $2,667,639$ \\
\hline Overall sales & $3,220,411$ & $-393,721$ & $2,826,690$ & 0 & 0.00 & $2,826,690$ \\
\hline Result & 292,765 & 123,043 & 169,721 & 5,576 & 16,246 & 159,051 \\
\hline
\end{tabular}


Production volume

Bdg $\quad 130,610$

Act 113,632
Analysis of variance

$000,000 /$ RSD

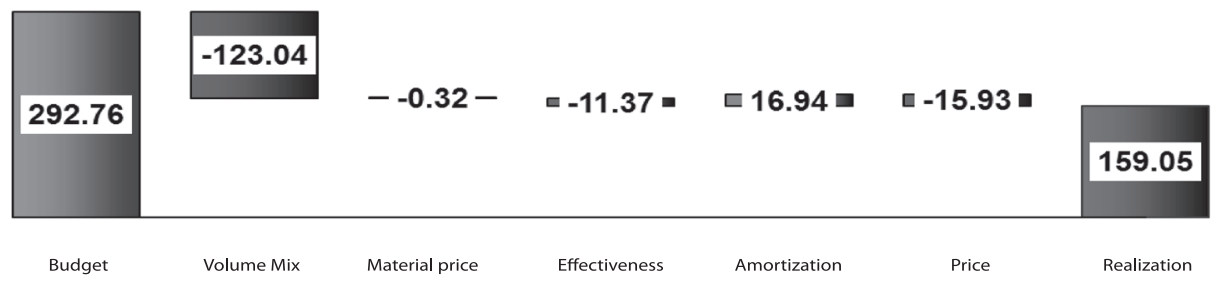

Graphic 1. Graphic overview of analysis of variance

We will briefly comment on the business results. As regards to the planned production volume, the company experienced a decrease in 16,978 units. The result correction of 123 million RSD is explained by difference in absorption of 154 million RSD (NB: page 10) and by positive mix of 31.3 million RSD. The company has generated ineffectiveness of transformation costs in the amount of 11.4 million $\mathrm{RSD}$, whereas effectiveness in direct labour is 3.4 million RSD. Thus, the company has shown ineffectiveness in indirect labour and costs of administrative workers. The costs of write-offs have been increased per product unit, which has led to ineffectivenes of 7.9 million RSD, as well as to excessive consumption of indirect material in the amount of 2.6 million RSD. On the other hand, savings have been done in services costs in the amount of 6 million RSD. Amortization costs are also less than planned as result of postponed investments, which has caused lower amortization costs of newly activated means.

When it comes to price variance, the variance of material price is particularly considered, due to the already mentioned influence on the overall result. In this case, the company has a negative effect on the prices of direct material in the amount of 320 thousand RSD. Regarding other costs, the biggest increase in prices is seen in direct labour, which is the consequence of correction of income for direct workers which has not been planned in the budget, as well as the consequence of unplanned overtime hours and working hours during the weekend. The increase in income refers to income of administrative workers, so the company has an increase in prices regaring these costs in the amount of 864 thousand RSD.

\section{SUMMARY}

The analysis of variance is a very significant tool for a company's management in order to be able to perceive the current result and the level of deviation, in relation to which certain actions can be taken for the purpose of correction and improvement of the company's performances. The analysis of variance indicates the company's departments which need to be taken care of, as well as where to focus their actions. The existence of good communication between the parties involved in the production process is crucial, whether these parties are directly or indirectly included. Eventually, we should comment on the software support which is used by the companies worldwide to facilitate business decision making process, but also to measure their performance and monitor the work of the overall system. The most famous software solutions in contemporary business are: SAP, Oracle, SAS and Microsoft solution. The leading solution is SAP, due to its functionality, expertise and representation in the biggest world companies. SAP is in charge only of business applications, and it enables collaboration, integration and connection of business processes by means of the state-ofthe art technologies. By system integration, financial managers get a unified image of all financial and business activities, as well as the ability to completely measure and manage risks, profits and performances of internal functions, but also the entire business system. SAP solutions have become the global practice and they represent the standards of business management for various industries.

In the times of high technological development, when the competition for gaining buyers has become the supreme goal of each company, companies have to find a way to keep up with the global tendencies and win over the competition by offering a product of the highest quality, with the lowest production costs. Finding the way to decrease production costs is the supreme goal of people employed in the production departments of companies. In order to follow the results, the analysis of variance is a very strong tool. If everyone contributes to the more effective usage of material, workforce, energy and resources, depending on their responsibilities, the company can offer better product and ensure benefits both for the buyer and the owner of the company.

\section{REFERENCES}

Barjaktarović, L., \& Milojević, M. (2014). Key aspects of cash managment in the company's business. Finansijsko izveštavanje $\mathrm{u}$ funkciji korporativnog upravljanja (str. 105-108). Beograd: Univerzitet Singidunum.

Bierman, J. (1987). Financial Accounting Theory. New York: MacMillan Company.

Cvetinović, M. (2013). Menadžerska ekonomija. Beograd: Univerzitet Singidunum.

Gowthorpe, C. (2008). Upravljačko računovodstvo. Beograd: Data status.

Hillier, J., \& Willett, R. (2006). The impact of depreciation-type adjustments on the distribution of accounting earnings. Accounting and Business Hesearch, 36(4), 309-335. 
Marjanović, V., Milojević, M., \& Simeunović, N. (2011). Značaj pokazatelja likvidnosti i zaduženosti proizvođača hrane i pića u Srbiji i Hravtskoj za sagledavanje strategijskog pozicioniranja. 8. Naučni skup sa međunarodnim učešćem Sinergija 2011 (str. 269-275). Biljeina: Univerzitet Sinergija.

Milojević, M., \& Dragan, M. (2014). Upravljanje tokovima gotovine u savremenom načinu poslovanja u Republici Srbiji. Finansijsko izveštavanje u funkciji korporativnog upravljanja (str.101-104). Beograd: Univerzitet Singidunum.
Petrović, Z. (2011). Upravljačko računovodstvo. Beograd: Univerzitet Singidunum.

PricewartehouseCoopers. (2007). The IFRS Manual of Accounting. London: $\mathrm{CCH}$.

\section{ANALIZA VARIJANSI REZULTATA PROIZVODNE KOMPANIJE}

\section{Apstrakt:}

U savremenom poslovanju koje je jako dinamično i podleže brzim promenama veoma je važno raspolagati tačnim i relevantnim informacijama o kretanjima u procesu proizvodnje i na osnovu toga donositi adekvatne odluke koje će obezbediti uspeh kompanije u budućnosti. Kako klasično računovodstvo nije u mogućnosti da odgovori na ove izazove, potrebno je naći način da se na bazi računovodstvenih kretanja, ali sa više detalja, omogući bolje razumevanje procesa proizvodnje i uticaja različitih faktora na krajnji rezultat i cenu koštanja proizvoda. Razvijeno je nekolilko različitih obračuna cene koštanja koje imaju prednosti i mane u zavisnosti od složenosti proizvodnje i zahteva menadžmenta. Analiza varijansi predstavlja alat pomoću kojeg finansijski kontrolori i i finansijsko rukovodstvo kompanija tumače odstupanja poslovnih rezultata u odnosu na rezultate predviđene budžetom ili revizijom budžeta tokom godine. Cilj ovog rada jeste da ispita varijanse rezultata proizvodne kompanije, koja je rezultat dobrog upravljačkog računovodstva. U radu se daje primer jedne proizvodne kompanije, kao i tok od budžeta (koji predstavlja osnovu za analizu varijansi) do realizacije i analize odstupanja između ova dva scenarija.

\section{Ključne reči:}

analiza varijansi,

budžet,

planiranje,

menadžment,

poslovni rezultat. 